\title{
Effects of Storage Time on External and Internal Characteristics of Lutein Enriched Eggs
}

\author{
Kanda Lokaewmanee and Peeyanut Meesrri \\ Faculty of Natural Resources and Agro-Industry, Kasetsart University, Chalermphrakiat Sakon Nakhon Province Campus, Sakon \\ Nakon 47000, Thailand
}

\begin{abstract}
In this paper, the effects of storage time on the external and internal characteristics of lutein enriched eggs were studied. A total of 330 lutein eggs were stored at room temperature $\left(30^{\circ} \mathrm{C}\right)$ for periods of $0,3,5,7,9,11,13,15,17,19$ and $21 \mathrm{~d}$, respectively. At the end of each storage period, 30 lutein eggs were evaluated for egg quality. Storage time from $0 \mathrm{~d}$ to $21 \mathrm{~d}$ did not affect the eggshell thickness, shell ratio and yolk color $(P>0.05)$. The effect of days in storage was statistically significant on the albumen ratio and Haugh unit $(P<0.05)$, both of which decreased with increasing days of storage. Conversely, egg water loss and the yolk ratio increased with increasing days of storage $(P<0.05)$. At the end of storage, the lutein value in the eggs was close to the value at the beginning of storage. The results indicated that storage time did not produce an adverse effect on the eggshell thickness, shell ratio, yolk color and concentration of lutein in lutein enriched eggs.
\end{abstract}

Key words: Storage time, characteristics, lutein enriched eggs.

\section{Introduction}

Lutein is considered as a nutrient that prevents age-related macular degeneration [1] by aiding in filtering the damage of blue light and sunlight [2]. Macular degeneration is the leading cause of blindness, resulting in progressive and irreversible loss of central region vision [3]. Moreover, lutein has been known to have excellent antioxidant ability, because of its capacity to quench single oxygen and scavenge peroxyl radicals in cellular membrane [4]. As lutein is not synthesized in the body, dietary ingestion is the only source to meet the requirements of lutein to prevent macular degeneration [4]. The intake of lutein in adults is less than $1 \mathrm{mg} / \mathrm{d}$, which is much less than the preventive level tested for these nutrients [5]. The dietary matrix and the type of lutein absorption indicated that the egg yolk is the most effective way to increase lutein bioavailability, although the amounts are relatively lower than other lutein-rich vegetables,

Corresponding author: Kanda Lokaewmanee, Ph.D., research fields: animal science, poultry production, poultry nutrition, meat and egg. including spinach [6]. Normally, egg contains $0.14 \mathrm{mg}$ to $0.16 \mathrm{mg}$ of lutein [7]. Lokaewmanee et al. [8] showed that layers fed $50 \mathrm{mg} / \mathrm{kg}$ dietary lutein could increase the lutein concentration in their eggs. All food has a limited shelf life, which varies depending on the type of food and storage conditions. The egg is varying perishable food product, which could lose its quality rapidly during the period between storage and consumption. Egg quality can be affected by the environmental conditions, such as temperature and humidity of storage, as well as the gaseous environment and storage time.

However, there is limited information on the storage time of lutein eggs with regard to egg quality and lutein concentration in the egg. Therefore, the present study was conducted to investigate the effect of storage time on the external and internal characteristics of lutein enriched eggs.

\section{Materials and Methods}

\subsection{Collection of Lutein Enriched Eggs}

Lutein enriched eggs were collected after the hens 
had been fed dietary lutein (50 mg/kg of feed) for three weeks. In total, 330 lutein eggs were stored at room temperature (about $30^{\circ} \mathrm{C}$ ). According to storage time, eggs were weighed, broken and evaluated after 0 , $3,5,7,9,11,13,15,17,19$ and $21 \mathrm{~d}$ of storage.

\subsection{Characteristics Measurement after Storage}

Thirty lutein eggs from each the period of storage were measured for egg water loss and egg quality. At first, the egg weight was recorded by using an electronic digital balance. Each egg was broken onto a metal plate, and the height of the albumen was measured as the distance between the metal plate and the electrode was placed on top of the thick part of the egg. Then, the weights of the albumen and egg yolk were measured using an electronic digital balance. The shell was dried at room temperature and weighed according to the methods described by Scott and Silversides [9]. The shell thickness was measured at three different parts (equator, top and truncated edge) of the shell in each egg using a micrometer, and the mean was recorded as the shell thickness. Yolk color was measured by a subjective method using the Roche yolk color fan (Roche Ltd., Basel, Switzerland). At the start (day 0 of storage) and the end (day 21 of storage), lutein in the eggs was analyzed by the Institute of Food Research and Product Development, Kasetsart University, Bangkok, Thailand. Then, the egg water loss, shell ratio, albumen ratio, yolk ratio and Haugh unit were respectively calculated as Eqs. (1)-(5):

$$
\begin{aligned}
& \text { Egg water loss }=\frac{\text { egg weight }- \text { egg broken we }}{\text { egg weight }} \\
& \text { Shell ratio }=\frac{\text { shell weight }}{\text { egg weight }} \times 100 \\
& \text { Albumen ratio }=\frac{\text { albumen weight }}{\text { egg weight }} \times 100 \\
& \text { Yolk ratio }=\frac{\text { yolk weight }}{\text { egg weight }} \times 100
\end{aligned}
$$$$
\text { Haugh unit }=100 \times \log \left(H-1.7 W^{0.37}+7.6\right)
$$

where, $H$ = observed height of the albumen (mm); $W$ = weight of egg (g).

\subsection{Statistical Analysis}

All data were statistically analyzed by Duncan's multiple test [10], using statistical analysis system (SAS) [11]. The level of significance was 0.05 unless or otherwise stated.

\section{Results and Discussion}

A summary of the external and internal characteristics of lutein enriched eggs after storage is presented in Table 1. Storage of $0 \mathrm{~d}$ to $21 \mathrm{~d}$ did not affect the eggshell thickness, shell ratio and yolk color $(P>0.05)$. The effect of storage time was statistically significant on the egg water loss, albumen ratio, yolk ratio and Haugh unit $(P<0.05)$. The egg water loss and yolk ratio significantly increased with the increased storage time. These findings are in agreement with those of Silversides and Villeneuve [12], who reported a significant egg water loss increase of $1.94 \mathrm{~g}$ after storage for $10 \mathrm{~d}$ at $29^{\circ} \mathrm{C}$. Tilki, and Saatci [13] reported that yolk ratio significantly increases of $3.34 \%$ after storage for $35 \mathrm{~d}$ at room temperature (about $15-18{ }^{\circ} \mathrm{C}$ ). Dramatic deterioration was observed in both the albumen ratio and Haugh unit due to the storage time. Samli et al. [14] had reported that albumen ratio decreases of $5.40 \%$ after storage for $35 \mathrm{~d}$ at room temperature (about $15-18{ }^{\circ} \mathrm{C}$ ). In general, the storage time and temperature appear to be the most critical factors affecting the Haugh unit [9]. These results are in agreement with those of Samli et al. [14], who reported a significant $(P<0.05)$ decrease from 91.4 to 40.6 in the Haugh unit in eggs after $10 \mathrm{~d}$ of storage at $29^{\circ} \mathrm{C}$. Most of these changes in egg quality in term of albumen ratio, yolk ratio and Haugh unit were attributed to water loss by evaporation through the pores in the shell and the escape of carbon dioxide from albumen [15]. Interestingly, the concentration of egg lutein was not significantly different throughout $21 \mathrm{~d}$ of storage. The 
Table 1 Effects of egg storage time on external and internal characteristics in lutein eggs (mean \pm SD, $n=30)$.

\begin{tabular}{|c|c|c|c|c|c|c|c|c|c|c|c|c|}
\hline \multirow{2}{*}{ Characteristics } & \multicolumn{11}{|c|}{ Days of storage } & \multirow{2}{*}{$P$ value } \\
\hline & 0 & 3 & 5 & 7 & 9 & 11 & 13 & 15 & 17 & 19 & 21 & \\
\hline $\begin{array}{l}\text { Egg water loss } \\
\text { (\%) }\end{array}$ & - & $1.06 \pm 0.02^{\mathrm{d}}$ & $1.11 \pm 0.02^{\mathrm{d}}$ & $1.71 \pm 0.01^{\mathrm{d}}$ & $3.87 \pm 0.02^{\mathrm{C}}$ & $4.12 \pm 0.01^{\mathrm{bc}}$ & $4.67 \pm 0.04^{\mathrm{b}}$ & $5.81 \pm 0.06^{b}$ & $7.95 \pm 0.03^{\mathrm{a}}$ & $8.24 \pm 0.05^{\mathrm{a}}$ & $9.24 \pm 0.02^{\mathrm{a}}$ & $<0.01$ \\
\hline $\begin{array}{l}\text { Eggshell } \\
\text { thickness (mm) }\end{array}$ & $0.40 \pm 0.01$ & $0.41 \pm 0.01$ & $0.40 \pm 0.01$ & $0.41 \pm 0.01$ & $0.40 \pm 0.01$ & $0.39 \pm 0.01$ & $0.38 \pm 0.01$ & $0.40 \pm 0.01$ & $0.41 \pm 0.01$ & $0.41 \pm 0.01$ & $0.39 \pm 0.01$ & 0.59 \\
\hline $\begin{array}{l}\text { Shell ratio } \\
\text { (\%) }\end{array}$ & $10.37 \pm 0.22$ & $10.69 \pm 0.24$ & $10.02 \pm 0.14$ & $10.26 \pm 0.24$ & $9.80 \pm 0.18$ & $10.03 \pm 0.16$ & $11.03 \pm 0.18$ & $10.77 \pm 0.14$ & $10.88 \pm 0.20$ & $11.41 \pm 0.21$ & $10.94 \pm 0.10$ & 0.24 \\
\hline $\begin{array}{l}\text { Albumen ratio } \\
\text { (\%) }\end{array}$ & $65.53 \pm 0.48^{\mathrm{a}}$ & $64.89 \pm 0.47^{\mathrm{a}}$ & $63.46 \pm 0.27^{\mathrm{a}}$ & $60.62 \pm 0.49^{\mathrm{ab}}$ & $60.37 \pm 0.55^{\mathrm{ab}}$ & $58.10 \pm 0.60^{b}$ & $53.10 \pm 0.60^{b}$ & $50.25 \pm 0.42^{\mathrm{bc}}$ & $47.23 \pm 0.46^{c}$ & $46.62 \pm 0.28^{c}$ & $46.40 \pm 0.48^{\mathrm{c}}$ & $<0.01$ \\
\hline $\begin{array}{l}\text { Yolk ratio } \\
\text { (\%) }\end{array}$ & $27.37 \pm 0.35^{c}$ & $27.88 \pm 0.42^{\mathrm{c}}$ & $29.64 \pm 0.22^{\mathrm{b}}$ & $30.39 \pm 0.37^{\mathrm{ab}}$ & $30.26 \pm 0.46^{\mathrm{ab}}$ & $31.01 \pm 0.59^{\mathrm{a}}$ & $31.37 \pm 0.41^{\mathrm{a}}$ & $31.93 \pm 0.40^{\mathrm{a}}$ & $31.45 \pm 0.25^{\mathrm{a}}$ & $33.88 \pm 0.30^{\mathrm{a}}$ & $34.99 \pm 0.41^{\mathrm{a}}$ & $<0.01$ \\
\hline Haugh unit & $76.81 \pm 0.48^{\mathrm{a}}$ & $60.02 \pm 0.35^{\mathrm{b}}$ & $52.83 \pm 0.25^{c}$ & $51.02 \pm 0.73^{c}$ & $40.68 \pm 0.39^{\mathrm{d}}$ & $39.68 \pm 0.38^{\mathrm{d}}$ & $37.19 \pm 0.40^{\mathrm{d}}$ & $33.70 \pm 0.50^{\mathrm{e}}$ & $26.04 \pm 0.27^{\mathrm{f}}$ & $14.70 \pm 0.28^{g}$ & $10.15 \pm 0.20^{\mathrm{g}}$ & $<0.01$ \\
\hline Yolk color & $12.40 \pm 0.20$ & $12.35 \pm 0.20$ & $12.46 \pm 0.20$ & $12.01 \pm 0.20$ & $12.40 \pm 0.20$ & $12.40 \pm 0.20$ & $12.40 \pm 0.23$ & $12.20 \pm 0.20$ & $12.22 \pm 0.20$ & $12.10 \pm 0.20$ & $12.40 \pm 0.20$ & 0.61 \\
\hline $\begin{array}{l}\text { Lutein } \\
(\mu g / 100 \mathrm{~g})\end{array}$ & 2,944.90 & - & - & - & - & - & - & - & - & - & 2,791.00 & 0.72 \\
\hline
\end{tabular}

${ }^{\mathrm{a}-\mathrm{g}}$ Means in the same row with different superscripts differ significantly $(P<0.05)$. Yolk color was scored by the Roche yolk color fan with 15 sample colors ranging from 1 (lightest) to 15 (darkest). -: not detected. 
reason for this is not clear and further research is needed to clarify this point.

\section{Conclusions}

The results suggested that the eggshell thickness, shell ratio, yolk color and concentration of egg lutein were not affected during $0 \mathrm{~d}$ to $21 \mathrm{~d}$ of storage at $30{ }^{\circ} \mathrm{C}$ for lutein enriched eggs. Lutein enriched eggs stored for $21 \mathrm{~d}$ at $30{ }^{\circ} \mathrm{C}$ still maintain relatively good internal quality characteristics for human consumption.

\section{References}

[1] Snodderly, D. M. 1995. "Evidence for Protection against Age-Related Macular Degeneration by Carotenoids and Antioxidant Vitamins.” Am. J. Cli. Nutr. 62 (6): 1448-61.

[2] Sperling, H. G., Johnson, C., and Harwerth, R. S. 1980. "Differential Spectralphotic Damage to Primate Cones." Vision Res. 20 (12): 1117-25.

[3] Leeson, S., and Caston, C. R. 2004. "Enrichment of Egg with Lutein.” Poult. Sci. 83 (10): 1709-12.

[4] Lim, B. P., Nagao, A., Terao, J., Tanaka, K., Suzuki, T., and Takama, K. 1992. "Antioxidant Activity of Xanthophylls on Peroxyl Radical-Mediated Phospholipid Peroxidation.” Biochim. Biophys. Acta 1126 (2): 178-84.

[5] Grando, F., Olmedilla, B., and Blanco, I. 2003. "Nutritional and Clinical Relevance of Lutein in Human Health.” Br. J. Nutr. 90 (3): 487-502.

[6] Surai, P. F., MacPherson, A., Speake, B. K., and Sparks, N. H. 2000. "Designer Egg Evaluation in a Controlled
Trial.” Eur. J. Clin. Nutr. 54 (4): 298-305.

[7] Goodrow, E. F., Wilson, T. A., Houde, S. C., Vishwanathan, R., Scollin, P. A., Handelman, G., and Nocolas, R. J. 2006. "Consumption of One Egg per Day Increases Serum Lutein and Zeaxanthin Concentration in Older Adults without Altering Serum Lipid and Lipoprotein Cholesterol Concentrations.” J. Nutr. 136 (10): 2519-24.

[8] Lokaewmanee, K., Yamauchi, K., Komori, T., and Saito, K. 2012. "Effects of Dietary Lutein on Raw and Boiled Egg Yolk Color and Lutein Concentration in Egg Yolk.” In Proceeding of the 15th AAAP Animal Science Congress, 2597-02.

[9] Scott, T. A., and Silversides, F. G. 2000. "The Effect of Storage and Strain of Hen on Egg Quality.” Poult. Sci. 79 (12): 1725-9.

[10] Duncan, D. B. 1955. "Multiple Range and Multiple F Tests.” Biometrics 11: 1-42.

[11] SAS Institute. 1996. SAS User's Guide: Statistical Version 7.0. Cary, NC: SAS Institute Inc..

[12] Silversides, F. G., and Villeneuve, P. 1994. "Is the Haugh Unit Correction for Egg Weight Valid for Eggs Stored at Room Temperature.” Poult. Sci. 73 (1): 50-5.

[13] Tilki, M., and Saatci, M. 2004. "Effects of Storage Time on External and Internal Characteristics in Partridge (Alectoris graeca) Eggs.” Revue. Med. Vet. 11: 561-4.

[14] Samli, H. E., Agma, A., and Senkoylu, N. 2005. "Effects of Storage Time and Temperature on Egg Quality in Old Laying Hens.” J. Appl. Poult. Res. 14 (3): 548-53.

[15] Robinson, D. S. 1987. "The Chemical Basis of Albumen Quality.” In Egg Quality: Current Problems and Recent Advances, edited by Wells, R. G., and Belyavin, C. G. London: Butterworths, 179-91. 